\title{
THE IMPORTANCE-PERFORMANCE ANALYSIS (IPA) OF EMPLOYER EVALUATIONS OF EMPLOYABILITY COMPETENCIES IN VOCATIONAL EDUCATION
}

\author{
Anita Lice \\ University of Latvia, Employers' Confederation of Latvia, Latvia \\ E-mail: anita.lice@gmail.com
}

\begin{abstract}
The focus of this research is to evaluate the importance of developing different employability competencies in vocational education. The Importance - Performance Analysis (IPA) was used to measure the priority areas in developing employability of graduates in vocational education institutions in Latvia from the employers' perspective. Total 700 companies participated in this research. A list of 17 employability competencies was rated using a five-point Likert scale. Employers rated the relative importance of employability competencies in the labour market, followed by another rating of performance of vocational education institutions in developing these competencies. The purpose of the research is not only to measure the actual satisfaction and performance level, but also to highlight important areas for improvement. The IPA is a clear and powerful tool for policy makers and managers to find out attributes that are doing well and the attributes that need to be improved and require immediate action. The results are useful in identifying priority areas for curriculum development of vocational education to facilitate employability of graduates.
\end{abstract}

Keywords: employability competencies, importance-performance analysis, employer evaluations, vocational education.

\section{Introduction}

During the industrial revolution 4.0 when the skills requirements of the workforce are changing as rapidly as never, it is important for students and young professionals to prepare for a long, although hard-to-predict career. Often graduates find that their education did not properly prepare them for the skills needed for fast-changing industries such as manufacturing (Arkan, 2016). For governments and educational institutions, this means adapting new priorities in education standards and curriculum and facilitating introduction of new teaching and learning methods to keep up with the demands of the new digital labour market.

This research focusses on vocational education and attempts to answer the question, which competencies should be prioritized in its curriculum to ensure employability of graduates in the rapidly changing labour market in the long term. Data indicates that vocational education is not good enough at developing employability competencies for sustainable employment throughout the career even though it generally well ensures the transition to the labour market to its recent graduates. In comparison to the general education, vocational education provides an easier transition from education to the labour market, higher employment rates and lower unemployment rates (European Commission, 2015; Flisi \& Goglio, 2015) to its recent graduates, however later in life the benefits of vocational education diminish considerably. Hanushek, Schwerdt, Woessmann, \& Zhang (2017) compared employment rates across different ages for people with general education and vocational education for 11 countries and found strong and 
Anita LICE. The importance-performance analysis (IPA) of employer evaluations of employability competencies in vocational education

PROBLEMS

OF MANAGEMENT IN THE $21^{\text {st }}$ CENTURY Vol. 13, No. 1, 2018

robust support for a trade-off between better school-to-work transition for vocational education graduates and better labour market outcomes later in life for general education graduates. A similar problem can also be observed in Latvia, where the biggest share of the unemployed people at the end of June 2017 were people with vocational education qualifications (36.3\%). Half of them $-50.4 \%$ were people over 50 years old (Public Employment Service, 2017) (June 2017) and 73.3\% - over 40 years old (Public Employment Service, 2016) (September, 2016). Whereas higher education graduates demonstrate better labour market outcomes than any other lower level education in terms of employment, unemployment, income, job satisfaction and even life satisfaction (Commission/EACEA/Eurydice, 2015; European Commission, 2015; Eurostat, 2015; Public Employment Service, 2016). Higher education graduates are also leaders in terms of participation in lifelong learning (Central Statistical Bureau, 2013; European Commission, 2015) which inevitably helps higher education graduates maintain their employability throughout their working careers. Therefore, there are significant inefficiencies in VET that hinder employability of VET graduates later in their life as their skills become obsolete.

Considering these aspects, it is important to seek ways how to develop employability of vocational education graduates to bring labour market outcomes of vocational education graduates closer to those of higher education. According to Yorke \& Knight (2004), employability is "a set of achievements - skills, understandings and personal attributes - that make graduates more likely to gain employment and be successful in their chosen occupations, which benefits themselves, the workforce, the community and the economy" (Yorke \& Knight, 2004, p. 3). The Employability researchers (for example, Benett, Dunne, \& Carre, 1999; Fugate, Kinicki, \& Ashforth, 2014; Hillage \& Pollard, 1998; Kail, Plimmer, Ogain, Harries, \& Copps, 2014; Yorke \& Knight, 2004) have developed different models of that help to explain the attributes, including competencies, facilitating employability. One of the best known is the CareerEDGE model which was developed by Pool \& Sewell (2007). The model explains the way in which five factors, namely, career development learning, experience, degree subject knowledge, understanding and skills, generic skills, and emotional intelligence, can lead towards employability through a complex interaction with self-esteem, self-efficacy and self-confidence. Indeed, the employer surveys in Latvia confirm that there is a rising demand that students should develop transferable or generic competencies in addition to subject-specific qualifications (Project and Quality Management Ltd, 2014; Līce, 2017). It has not been researched, however, how well vocational education ensures development of these, as well as other employability competencies, in its graduates; and which employability competencies should be addressed in vocational education to ensure a graduate's employability in a longer term.

Therefore, the aim of the research is with the help of the Importance-Performance Analysis (IPA) to analyse the employers' opinions on the importance of employability competencies in the Latvian labour market and the performance of the vocational education institutions in developing them, as well as to highlight important areas for improvement. IPA is a powerful evaluation tool for practitioners and academics to prescribe the prioritisation of attributes for improvement and it can also provide guidance for strategic development (Slack, 1994). The results of the IPA analysis indicate the priority areas for curriculum development of vocational education to facilitate employability of graduates. As this research is not occupation or sectorspecific, it is limited only to those employability competencies which are general enough to be equally applicable to all vocational education occupations.

\section{Methodology of Research}

\section{General Background}

A survey of companies was carried out to find out employers' views on employability competencies. The general population for the questionnaire survey includes all active companies 
working in Latvia. The sample size is comprised of 750 companies. A sample was created by multistage cluster sampling method. The answers to the questionnaire were collected by the research centre SKDS Ltd, which is a well-known independent research company in Latvia. First, the companies which already had participated in the surveys of the research centre "SKDS" were contacted, then the companies from the public databases of companies were selected according to the random sampling method. The data were collected in two phases: 1) from 27.03.2017 until 04.04.2017, when 499 internet questionnaires were collected, and 2) from 05.04.2017. - 03.05.2017, when 251 telephone interviews were conducted by 19 interviewers. For telephone interviews, there were 587 cases of non-response: in $87.6 \%$ of these cases respondents didn't want to participate in the interview, 7\% - didn't have time and $5.5 \%$ stopped answering during the interview. The collected data were weighted according to the statistics of the Central Statistical Bureau of Latvia of 2015 on the distribution of companies by industry, size and location of a company to ensure their representativeness. Considering the size of the general population, the margin of error (MOE) at 95\% confidence level is $+/-4.0 \%$.

Considering that the companies might have limited knowledge of vocational education, in addition to the commonly asked questions about the company profile, the questions on whether they have employees with vocational qualifications and whether they have had trainees during last 5 years were included in the questionnaire. The companies that responded positively were considered experts, taking into account their direct experience with the results of vocational education through employing vocational education graduates or trainees. To assess the importance of different employability competencies in the labour market and the performance of vocational education, the questions on employer perception of the importance of certain competencies for employment in their companies (Q4) and on the extent to which these competencies could be developed in vocational education in Latvia (Q5) were included in the questionnaire. Q4 and Q5 were developed as Likert-type questions with bi-directional scale of 5 possible answers with one neutral option. The list of 17 items to be assessed was elaborated, based on the list of employability competencies which resulted from operationalisation (Pool, Qualter, \& Sewell 2014) of the CareerEDGE employability model (Pool \& Sewell, 2007). The list of items was adapted to the needs of the target audience of employers and limitations of the questionnaire. The items were reviewed by a member of academic staff and experienced sociologists, which resulted in some refinements.

\section{Data Analysis}

The author used the IPA approach for analysing employers' opinions. IPA is a method developed by Martilla \& James (1977), widely used in marketing and management research. It combines measures of customers' perceived importance (I) and performance (P) into a twodimensional coordinate system to facilitate data interpretation, where performance is placed on the $\mathrm{x}$ axis and the importance - on y axis. Quadrant I indicates an area of high importance and high performance, quadrant II - high importance and low performance, quadrant III - low importance and low performance, and quadrant IV - low importance and high performance. The cross of the axes is determined by the median values of the data $(2.95,4.13)$ as suggested for situations when a true interval scale could not be assumed (Sever, 2014). An upward sloping $45^{\circ}$ diagonal line is inserted in the graph to separate the regions of different priorities as suggested by Bacon (2003). The points above the line depict an area of high priority for improvement and opportunity $(\mathrm{I}>\mathrm{P})$, while the region below suggests low priorities.

The data were analysed using free, open-source programming language and environment for statistical computing and graphics "R". The following analysis methods were used: descriptive statistics, Cronbach's alpha, KMO test, frequencies, individual paired-samples t-test. 
Anita LİCE. The importance-performance analysis (IPA) of employer evaluations of employability competencies in vocational education

OF MANAGEMENT

IN THE $21^{\text {st }}$ CENTURY

Vol. 13 , No. 1,2018

\section{Results of Research}

The profile of companies involved in the survey is described in the Table 1.

Table 1. Profile of companies involved in the survey.

\begin{tabular}{|c|c|c|c|}
\hline No. & Categorial variable & Description & $\begin{array}{l}\text { Percentage } \\
\text { distribution in } \\
\text { sample }\end{array}$ \\
\hline \multirow{4}{*}{1} & \multirow{4}{*}{ Sector } & Production & 21.6 \\
\hline & & Trade & 15.2 \\
\hline & & Construction & 7.2 \\
\hline & & Services & 56.0 \\
\hline \multirow{3}{*}{2} & \multirow{3}{*}{ Number of employees } & 1-9 employees & 62.3 \\
\hline & & 10-49 employees & 24.4 \\
\hline & & 50 or more employees & 13.3 \\
\hline \multirow{3}{*}{3} & \multirow{3}{*}{$\begin{array}{l}\text { Employing employee(s) with voca- } \\
\text { tional education qualifications }\end{array}$} & Yes & 42.9 \\
\hline & & No & 52.8 \\
\hline & & Didn't provide information & 4.3 \\
\hline \multirow{3}{*}{4} & \multirow{3}{*}{$\begin{array}{l}\text { Have had trainees during last } 5 \\
\text { years }\end{array}$} & Yes & 47.2 \\
\hline & & No & 52.5 \\
\hline & & Didn't provide information & 0.3 \\
\hline
\end{tabular}

The value of Cronbach's alpha obtained for each employability competence was greater than 0.84 and therefore the data could be considered internally consistent. A Kaiser-MeyerOlkin (KMO) test confirmed that the sampling was adequate as the lowest KMO value was 0.79 .

The researcher visualized the differences of the opinions between companies employing workers with vocational qualifications and other companies, as well as between the companies which have had trainees in the last 5 years and other companies. As there were no significant differences observed in opinions, these different groups of companies were not considered separately in the further analysis.

The results of the survey indicate that more employers consider all of the employability competencies important than not important in the Latvian labour market. The relative frequencies of all negative, neutral and positive answers about the importance of employability competencies are provided in Figure 1. 
Anita LİCE. The importance-performance analysis (IPA) of employer evaluations of employability competencies in vocational education

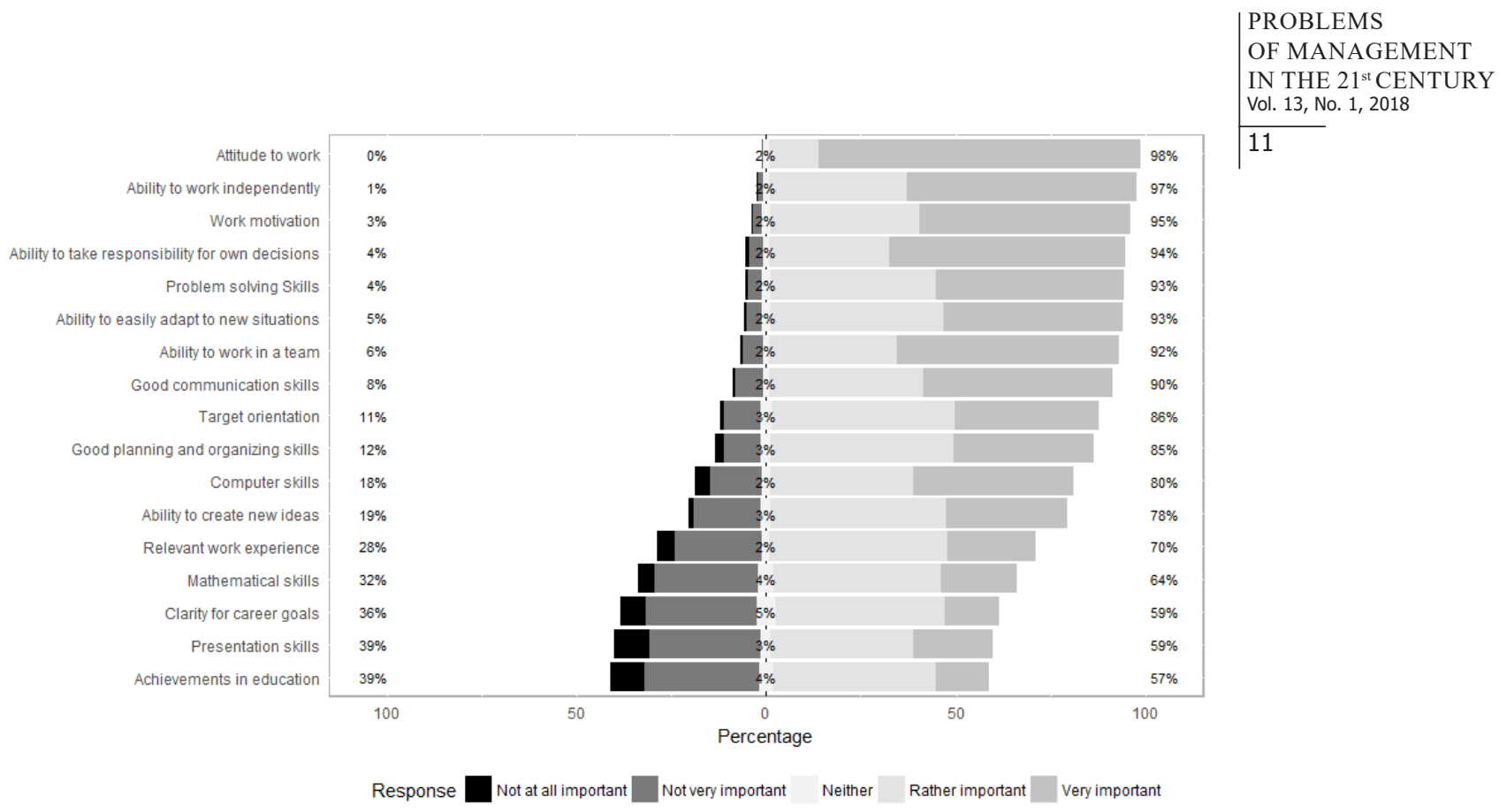

Figure 1. Evaluation of importance of employability competencies. Relative frequencies of negative, neutral and positive answers. $\mathbf{N}=750$.

The most important competencies for employability in the Latvian labour market according to the employers are the attitude to work, ability to work independently, work motivation, ability to take responsibility for one's own decisions, problem solving skills, adaptability, ability to work in a team and good communication skills.

The evaluation of performance of vocational education in Latvia in developing these competencies in students, however, is significantly lower. Individual paired-samples t-test was conducted to measure the gap between the importance and performance. All attributes except (5) "Presentation skills" and (9) "Achievements in education" showed a highly significant difference with $\mathrm{p}$ value lower than 0.01 . The relative frequencies of all negative, neutral and positive answers about performance of vocational education institutions are provided in Figure 2. According to the results, vocational education institutions in Latvia are best at developing computer and presentation skills, the ability to work in a team, mathematical skills, as well as acquiring the content of an education programme ("achievements in education"). Of all employability competencies, vocational education performs worst at developing the ability to take responsibility, ensuring relevant work experience, developing the appropriate attitude to work, good planning and organizing skills and problem-solving skills. 
Anita LİCE. The importance-performance analysis (IPA) of employer evaluations of employability competencies in vocational education

OF MANAGEMENT IN THE $21^{\text {st }}$ CENTURY Vol. 13 , No. 1, 2018

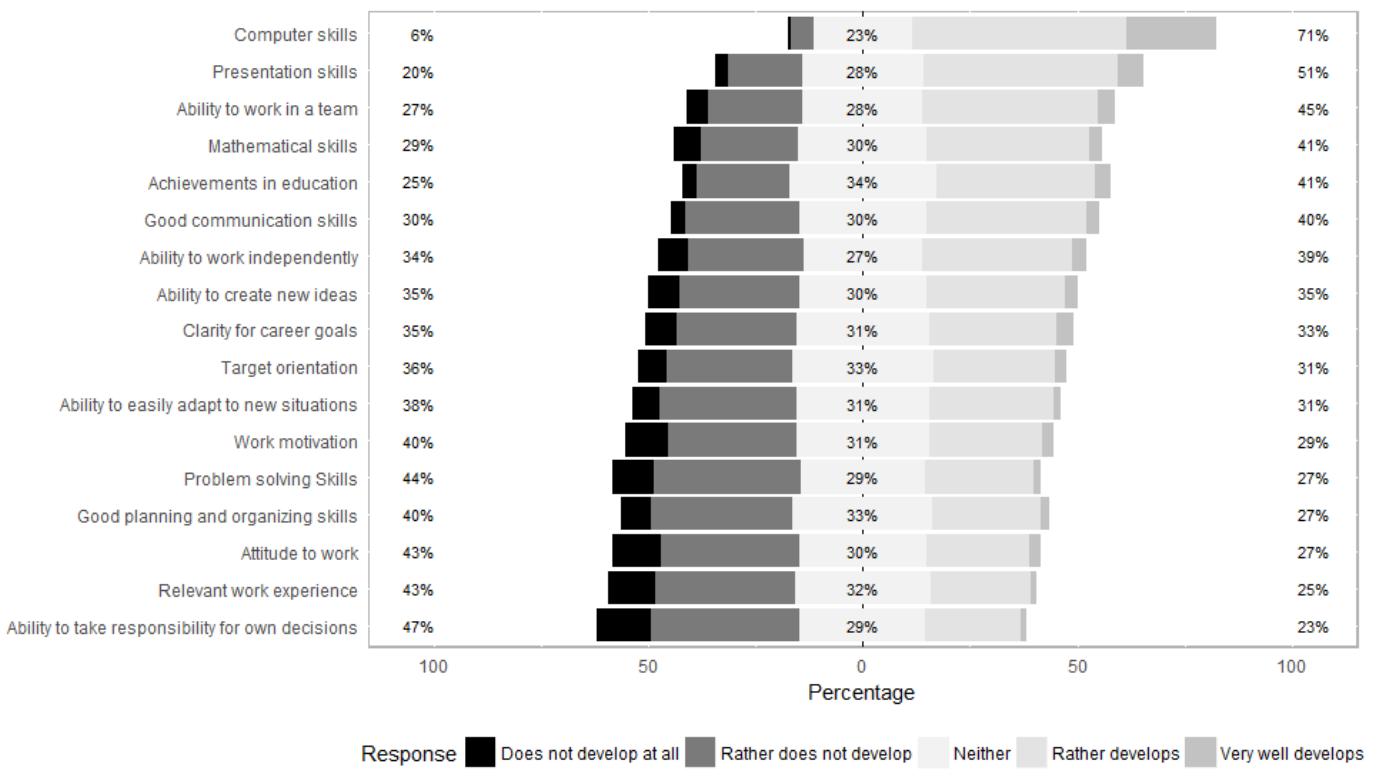

Figure 2. Evaluation of performance of vocational secondary educational institutions in developing employability attributes in students. Relative frequencies of negative, neutral and positive answers. $\mathbf{N}=$ 750.

The mean values and standard deviation of evaluations of importance of employability competencies and performance of vocational education institutions in developing employability competencies are included in table 2. The results of the Gaps analysis in a graphical form can be read from Figure 3 which indicates the priority areas for vocational education in Latvia to improve the employability of vocational education graduates. As it is shown in the graph (Figure 3), almost all the points are placed above the diagonal line at $45^{\circ}$ which separates the regions of different priorities. Moreover, the difference between I and P for all employability competencies except (5) and (9) is significant. Therefore, it could be concluded that there are no employability competencies which could be considered low-priority and that development of all of these competencies should be considered a high priority for vocational education institutions and policy makers in Latvia. 
Anita LİCE. The importance-performance analysis (IPA) of employer evaluations of employability competencies in vocational education

Table 2. Mean and standard deviations of evaluations of importance of employability competencies and performance of vocational education institutions in developing employabilty competencies. $\mathbf{N}=\mathbf{7 5 0}$.

\begin{tabular}{lcccc}
\hline & \multicolumn{2}{c}{ Importance } & \multicolumn{2}{c}{ Performance } \\
\hline & Mean & SD & Mean & SD \\
\hline Work motivation & 4.47 & 0.70 & 2.82 & 1.02 \\
\hline Target orientation & 4.12 & 0.94 & 2.91 & 0.97 \\
\hline Relevant work experience & 3.61 & 1.20 & 2.72 & 0.99 \\
\hline Problem solving skills & 4.38 & 0.76 & 2.75 & 1.00 \\
\hline Presentation skills & 3.32 & 1.34 & 3.34 & 0.94 \\
\hline Mathematical skills & 3.48 & 1.21 & 3.09 & 0.99 \\
\hline Planning and organizing skills & 4.07 & 1.00 & 2.81 & 0.96 \\
\hline Communication skills & 4.32 & 0.86 & 3.09 & 0.94 \\
\hline Computer skills & 4.01 & 1.16 & 3.86 & 0.83 \\
\hline Clarity for career goals & 3.30 & 1.22 & 2.95 & 1.02 \\
\hline Attitude to work & 4.83 & 0.44 & 2.75 & 1.03 \\
\hline Achievements in education & 3.23 & 1.27 & 3.16 & 0.92 \\
\hline Ability to work independently & 4.56 & 0.62 & 3.01 & 1.02 \\
\hline Ability to work in a team & 4.45 & 0.82 & 3.17 & 0.98 \\
\hline Ability to take responsibility for own decisions & 4.51 & 0.78 & 2.65 & 1.00 \\
\hline Ability to easily adopt to new situations & 4.35 & 0.76 & 2.88 & 0.95 \\
\hline Ability to create new ideas & 3.89 & 1.09 & 2.96 & 1.00 \\
\hline
\end{tabular}

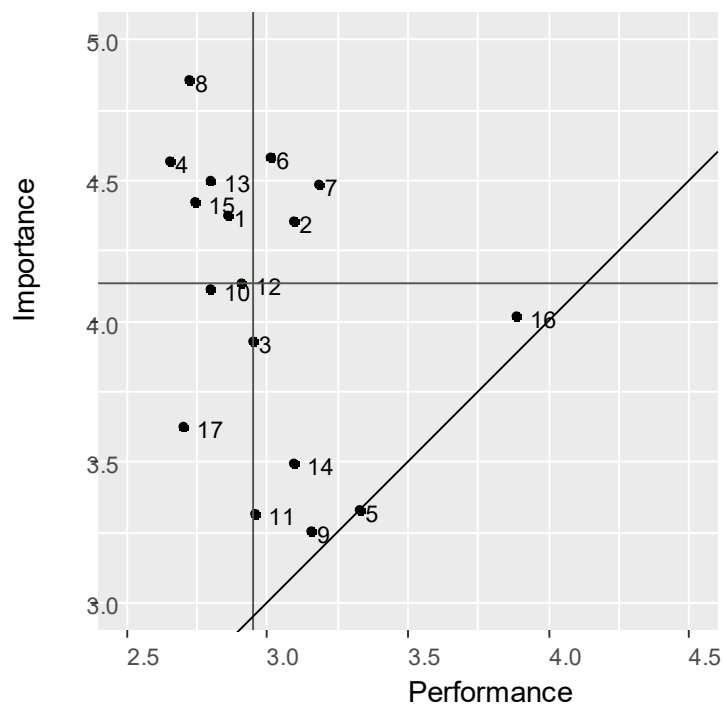

- 1 - Ability to easily adapt to new situations

- 4 - Ability to take responsibility for own decisions

- 7 - Ability to work in a team

- 10 - Good planning and organizing skills

- 13 - Work motivation

- 16 - Computer skills
PROBLEMS

OF MANAGEMENT

IN THE $21^{\text {st }}$ CENTURY

Vol. 13 , No. 1, 2018 
Anita LICE. The importance-performance analysis (IPA) of employer evaluations of employability competencies in vocational education

$\begin{array}{r}\text { PROBLEMS } \\ \text { OF MANAGEMENT } \\ \text { IN THE 21 } 1^{\text {st }} \text { CENTURY } \\ \text { Vol. 13, No. 1, } 2018 \\ \hline 14\end{array}$

The most urgent action, however, is needed to develop the employability competencies falling into the area of high importance in the labour market and low performance of vocational education institutions, namely, the development of appropriate attitude to work, ability to take responsibility for one's own decisions, problem solving skills, work motivation and adaptability. When it comes to items (6) "ability to work independently", (2) "communication skills", (10) "planning and organising skills" and (12) target orientation, they are situated too close to the axes, and the sampling error might change the results and potentially shift these points to quadrant II. Consequently, these competencies should also receive attention in deciding priorities.

\section{Discussion}

Considering the employer evaluation of the importance of the employability competencies, it could be concluded that the general CareerEDGE framework as developed by Pool \& Sewell (2007) reflects the opinions of the employers in Latvia. Other studies carried out in Latvia about skills demands (Lapiṇa, Ščeulovs, Gaile-Sarkane, Dubickis, \& N̦ikitina, 2017; Līce, 2017; Līce, Volkova, \& Zvaigzne, 2017; Project and Quality Management Ltd, 2013) have identified similar labour market demands. It is particularly typical to the labour market of Latvia that personal qualities and attitudes such as willingness to work and to learn and responsibility are highly valued. Other competencies, such as communication and cooperation skills, planning, organizational and decision-making skills, digital and technological competence, as well as skills to solve problems with creative, interdisciplinary solutions are also important in Latvian labour market and are aligned with the European trends according to the studies by Cedefop (2016). Nevertheless, considering that the factor structure of CareerEDGE employability competencies as developed by Pool, Qualter, \& Sewell (2014) has been adapted for the purposes of this research by translating and shortening the items, it would be useful to deepen the research by studying the reliability and validity of the assessment scale of the questionnaire to identify the possible improvements for future studies.

Achievements in education were evaluated by the employers as the least important for employability. Similar tendencies are also observed with regards to higher education (Līce, Volkova, \& Zvaigzne, 2017). This indicates that the employers do not fully trust the education system in Latvia regardless of the level or type of education but prefer to employ people they consider having the best attitude and personal qualities which would allow them to become motivated employees and learn new skills if necessary.

Low evaluation of performance of vocational education institutions in facilitating the development of personal qualities and attitudes (ability to take responsibility for one's own decisions - only $23 \%$ of positive answers, attitude to work - $27 \%$, work motivation - $29 \%$ ) might be explained both by the lack of attention in the education system to these issues and by the opinion of employers that it is beyond the competence of the education system. Even though a period of work experience in a form of work placement or work-based learning is an obligatory part of vocational education programmes, only $25 \%$ of employers believed that vocational education ensures opportunities for obtaining relevant work experience. This is aligned with the conclusion of Klāsons (2017, p. 4 - 5) that employers in Latvia do not consider work placements an alternative to work experience. A previous work experience is a much more important factor in the process of recruitment (for $77 \%$ of companies in 2014 and $92 \%$ - in 2017) than work placements (only 22\% of companies in 2014 and 26\% in 2017) (Klāsons \& Spuriņš, 2015; Klāsons, 2017).

The highest evaluations, on the contrary, were awarded to the competencies which are easier attributable to the education curriculum, such as computer skills ( $71 \%$ of positive evaluations), presentation skills (51\%), ability to work in a team (27\%), and mathematical skills $(29 \%)$. 
No doubt, many external factors, for example, socio-economic background, personal

\author{
PROBLEMS \\ OF MANAGEMENT \\ IN THE $21^{\text {st }}$ CENTURY \\ Vol. 13 , No. 1, 2018
}

qualities and values, extra-curriculum activities, experience, are very important in facilitating, or, just the opposite, hindering the development of employability competencies. However, it should be taken into account that education institutions can also contribute to facilitating employability (Perez, Kozovska, \& Garrouste, 2010), as long as it is their goal both in their strategy and daily practice. For example, Fallows \& Steven (2000) have described in detail, how the process of embedding employability into curriculum could take place and what benefits it brings to an educational institution.

The gaps analysis results indicated that the development of all employability competencies should receive attention in vocational education in Latvia, however those competencies which received the highest evaluation for their importance and lowest - for performance of vocational education institutions in developing them should be considered a priority in planning improvements in vocational education curriculum. It should be noted that many of these competencies are included in the Goleman's emotional intelligence competence framework (Goleman, 1998, p. 32). Rode, Arthaud-Day, Ramaswami, \& Howes (2017) have empirically proven that emotional intelligence has a significant, positive effect on subsequent salary levels as it helps individuals acquire the social capital needed to be successful in their careers. So far, little has been discussed and researched about the role of emotional intelligence in education and career success and the ways how to include it in the curriculum of education programmes along with other employability competencies. Further research in this area would be important and relevant not just for education researchers, but also for managers and policy makers.

Finally, this research demonstrates how the gaps analysis could be used effectively in education management to facilitate the planning of the curriculum and desirable learning outcomes, by taking into account the evaluations of the involved stakeholders.

\section{Conclusions}

The research has demonstrated that the gaps analysis could be effectively used in education management to facilitate the process of curriculum planning, considering the opinion of the stakeholders.

The results of the research indicate that the employers consider the attitude to work, ability to work independently, work motivation, ability to take responsibility for one's own decisions, problem solving skills, adaptability, ability to work in a team and good communication skills as the most important competencies for employability in the labour market in Latvia. The performance of vocational education institutions in developing employability competencies is evaluated as significantly lower than their importance in the labour market, except for presentation skills and achievements in education for which the importance and performance of vocational education institutions is balanced. Vocational education is best at developing computer and presentation skills, ability to work in a team, mathematical skills, as well as at ensuring the acquisition of the content of an education programme. Of all employability competencies, vocational education performs worst at developing the ability to take responsibility, ensuring relevant work experience, developing the appropriate attitude to work, good planning and organizing skills and problem-solving skills.

Considering the results of the gaps analysis, there are no employability competencies which could be considered low-priority in vocational education in Latvia, and therefore all employability competencies should receive sufficient attention in planning vocational education provision to improve the employability of graduates. The most urgent action, however, is needed to improve the development of the appropriate attitude to work, ability to take responsibility for one's own decisions, problem solving skills, work motivation and ability to adapt to different situations. 
Anita LICE. The importance-performance analysis (IPA) of employer evaluations of employability competencies in vocational education

\author{
PROBLEMS \\ OF MANAGEMENT \\ IN THE $21^{\text {st }}$ CENTURY \\ Vol. 13 , No. 1,2018 \\ 16 Acknowledgements
}

The collection of the data by company "SKDS" was financed by the company "Education and Employment Consultations" and the Employers' Confederation of Latvia within an Erasmus+ project "VET for Employment", No. 2014-1-LV01-KA202-000522.

\title{
References
}

Arkan, Ç. (2016). Thoughts on global workforce transformation in the Industry 4.0 era. Microsoft. Retrieved 15/06/2018 from https://news.microsoft.com/uploads/2017/02/Thoughts-on-globalworkforce-transformation-in-the-Industry-4.0-era.pdf

Bacon, D.R. (2003). A comparison of approaches to importance - performance analysis. International Journal of Market Research, 45 (1), 55-77.

Bennett, N., Dunne, E., \& Carré, C. (1999). Patterns of Core and Generic Skill Provision in Higher Education. Higher Education, 37 (1), 71-93. Retrieved 04/05/2018 from https://www.jstor.org/ stable/pdf/3448047.pdf?refreqid=excelsior\%3A479a60c92d23ee90c2ab0a7c6083a141

Cedefop. (2016). Future skill needs in Europe: Critical labour force trends. Retrieved 18/05/2018, from http://www.cedefop.europa.eu/en/publications-and-resources/publications/5559.

Central Statistical Bureau. (2013). Apsekojuma "Pieaugušo izglītība" rezultāti [Results of the survey "Adult Education"]. Central Statistical Bureau of Latvia.

Commission/EACEA/Eurydice. (2015). The European Higher Education Area in 2015: Bologna Process Implementation Report. Luxembourg: Publications Office of the European Union. https://doi. org/10.2797/128576.

European Commission. (2015). Education and Training Monitor 2015. Luxembourg. Retrieved 04/05/2018, from http://ec.europa.eu/dgs/education_culture/repository/education/library/ publications/monitor15_en.pdf

Eurostat. (2015). Quality of life. Facts and views. Retrieved 04/05/2018 from http://ec.europa.eu/eurostat/ documents/3217494/6856423/KS-05-14-073-EN-N/742aee45-4085-4dac-9e2e-9ed7e9501f23

Fallows, S., Steven, C. (2000). "Building employability skills into the higher education curriculum: a university wide initiative", Education + Training, 42 (2), 75-83, https://doi. org/10.1108/00400910010331620

Flisi, S., Goglio, V. (2015). Education And Youth Labour Market Outcomes: The Added Value Of Vocational Education and Training. Luxembourg: Publications Office of the European Union. Retrieved 05/06/2018 from http://publications.jrc.ec.europa.eu/repository/bitstream/JRC95019/ vet_technical\%20briefing_codes.pdf

Fugate, M., Kinicki, A. J., \& Ashforth, B. E. (2004). Employability: A psycho-social construct, its dimensions, and applications. Journal of Vocational Behavior, 65 (1), 14-38. https://doi. org/10.1016/j.jvb.2003.10.005

Goleman, D. (1998). Working with emotional intelligence. Bloomsbury, London.

Hanushek E. A., Schwerdt, G., Woessmann, L. \& Zhang, L. (2017). General Education, Vocational Education, and Labor-Market Outcomes over the Lifecycle. Journal of Human Resources, University of Wisconsin Press, 52(1), 48-87. DOI: 10.3368/jhr.52.1.0415-7074R

Hillage, J., \& Pollard, E. (1998). Employability: developing a framework for policy analysis. Labour Market Trends, 107 (85), 83-84. Retrieved 04/05/2018 from https://www.education.gov.uk/ publications/eOrderingDownload/RB85.pdf.

Kail, A., Plimmer, D., Ogain, E., Harries, E., Copps, J. (2014). The Journey to Employment (JET) Framework. Retrieved 04/05/2018 from https://www.thinknpc.org/publications/the-journey-toemployment/.

Klāsons, G. (2017). Izvērtējums par prakšu sistēmas uzlabojumiem Latvijā projekta "Kvalitatīvas prakses darba tirgum" kontekstā. [Evaluation of the system of work placements in Latvia in the context of the project "Quality work placements for the labour market"]. Retrieved 18/05/2018 from http:// www.lddk.lv/wp-content/uploads/2017/09/vet4e izvertejuma-zinojums.pdf.

Klāsons, G., \& Spuriņš, U. (2015). Pētījums par praǩšu pieejamību un kvalitāti Latvijā. Noslēguma zinojums. [Study on availability and quality of work placements in Latvia. Final report]. Riga: Employers' Confederation of Latvia (LDDK). Retrieved 18/05/2018 from http://www.lddk.lv/ wp-content/uploads/2015/06/LDDK_VET4E_Petijums_prakses.pdf. 
Anita LİCE. The importance-performance analysis (IPA) of employer evaluations of employability competencies in vocational education

Lapiņa, I., Ščeulovs, D., Gaile-Sarkane, E., Dubickis, M., N̦ikitina, T. (2017). Contemporary study process for enhancement of employability in the dynamic environment. In: Proceedings of the 21st World Multi-Conference on Systemics, Cybernetics and Informatics (WMSCI 2017), Vol.2, United States of America, Orlando, 8-11 July, 2017. Winter Garden, Florida: International Institute of Informatics and Systemics, 2017, 49-55.

Lîce, A. (2017). Involvement of employers in educating employees as a solution to the problem of skilled workforce shortage in Latvia. In I. Kangro, A. Fernāte, S. Kārkliņa, \& S. Kraže (Eds.), Challenges for high quality of adult education: Inter-national scientific conference proceedings, 111-123. Riga: Ministry of Edu-cation and Science.

Līce, A., Volkova. T., Zvaigzne, A. (2017). Meeting employers' expectations on employability competencies of higher education graduates. Paper presented at the 12th European Quality Assurance Forum. Retrieved 05/16/2018 from http://www.eua.be/Libraries/EQAF-2017/p16 lice_volkova_zvaigzne.pdf?sfvrsn $=0$.

Martilla, J. A., \& James, J. C. (1977). Importance - performance analysis. Journal of Marketing, 41 (1), 77-79.

Perez, E. A., Kozovska, K., Garrouste, C. (2010). Towards a benchmark on the contribution of Education and Training to Employability: a discussion note. European Commission Joint Research Centre. Retrieved 19/05/2018 from http://publications.jrc.ec.europa.eu/repository/bitstream/JRC60799/ lbna24624enc.pdf.

Pool, L. D., Qualter, P., \& Sewell, P. J. (2014). Exploring the factor structure of the CareerEDGE employability development profile. Education + Training, 56 (3), 303-313.

Pool, L., \& Sewell, P. (2007). The key to employability: developing a practical model of graduate employability.Education + Training,49(4),277-289.https://doi.org/10.1108/00400910710754435.

Project and Quality Management Ltd. (2013). Nākotnē stratēgiski pieprasītākās prasmes Latvijā [Strategically most demanded skills in future Latvia]. SIA Projektu un kvalitātes vadība. Retrieved 16/05/2018 from https://www.em.gov.lv/files/tautsaimniecibas_attistiba/1_Petijums_nakotne_ pieprasitakas_prasmes.pdf.

Project and Quality Management Ltd. (2014). Darba tirgus specifisko regionālo problēmu identificēšana un pasākumu izstrādāšana reǵionālā darba tirgus konkurētspējas stiprināšanai, pētījuma atskaite. [Identification of specific regional labor market problems and identification of measures for strengthen its competitiveness, the study report]. Retrieved 25/05/2017 from http://www.nva.gov. lv/docs/28_53abbd7c02ee19.16060069.pdf.

Public Employment Service. (2016). Pārskats par bezdarba situāciju valstī (septembris). [Overview of the unemployment situation in the country (June)]. Public Employment Service of Latvia. Retrieved 04/05/2018 from http://nva.gov.lv/docs/31_581c96f2665210.29571259.pdf.

Public Employment Service. (2017). Pārskats par bezdarba situāciju valstī (jūnijs) [Overview of the unemployment situation in the country (June)]. Public Employment Service of Latvia. Retrieved 04/05/2018 from http://nva.gov.lv/docs/31_599562a9017013.66486194.pdf.

Rode, J. C., Arthaud-Day, M., Ramaswami, A. \& Howes, S. (2017). A time-lagged study of emotional intelligence and salary. Journal of Vocational Behavior, 101 (2017), 77-89. https://doi. org/10.1016/j.jvb.2017.05.001.

Sever, I. (2014). Importance - performance analysis: A valid management tool? Tourism Management, 48, 43-53.

Slack, N. (1994). The importance-performance matrix as a determinant of improvement Priority. International Journal of Operations \& Production Management, 14 (5), 59-75. https://doi. org/10.1108/01443579410056803.

Yorke, M., \& Knight, P. T. (2004). Embedding employability into the curriculum. Learning and Employability, 3, 1-28. https://doi.org/10.1108/17561391111106016.

Received: May 25, 2018

Accepted: June 22, 2018

Anita Lice

Mg., PhD Student, University of Latvia; Manager of the Education and Employment Field, Employers' Confederation of Latvia, Riga, Latvia. E-mail: anita.lice@gmail.com 